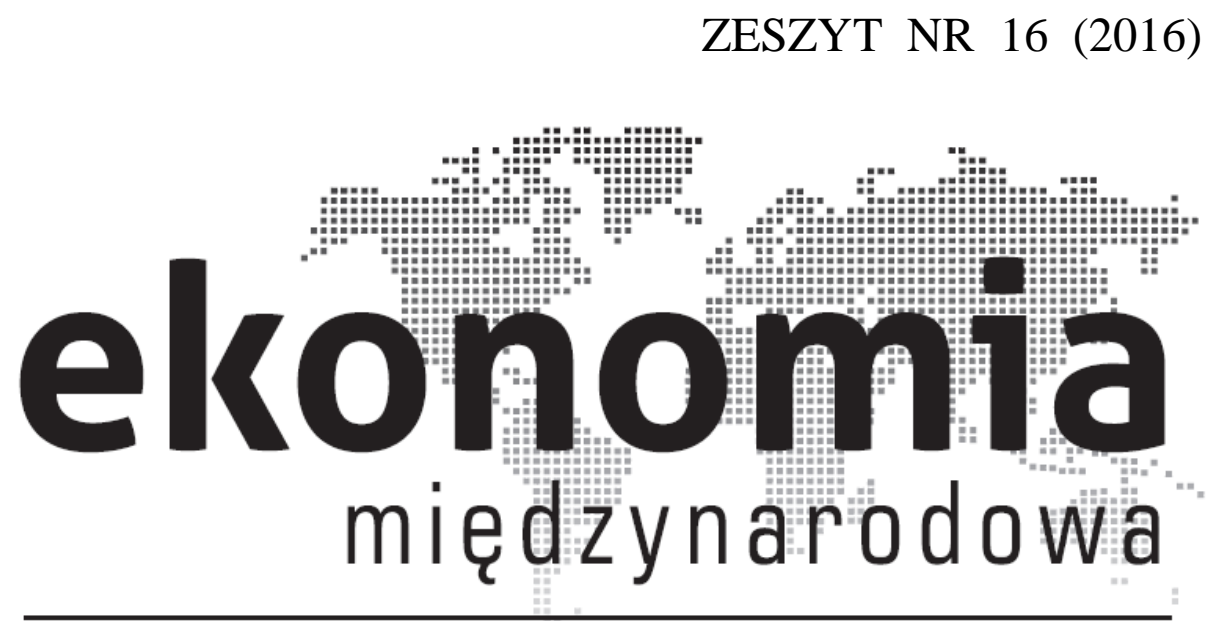

Ekonomia Międzynarodowa

Nr 16 (2016)

www.ekonomia-m.pl

ISSN: 2082-4440

EISSN: 2300-6005

Wydawca: Uniwersytet Łódzki

Wersja elektroniczna czasopisma jest wersją referencyjną
Publisher: University of Lodz

Electronic edition is the reference version of the journal
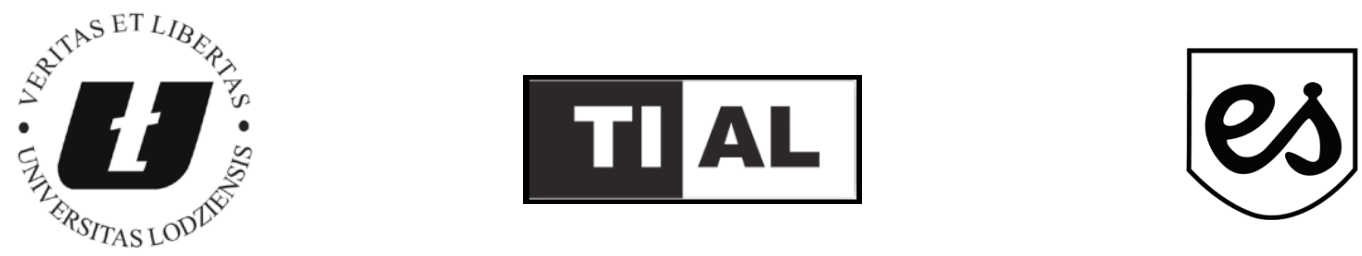


\section{Regional Innovation Systems in Sweden}

Joanna Ligenzowska ${ }^{1}$

\section{Introduction}

The world has changed. Markets are global. Science is an increasingly competitive endeavour. Innovation is becoming the most important engine of growth and jobs in the emerging knowledge-based economy (European Parliament 2009). The concept of a "learning economy" or "knowledge-based economy" is based on the idea that innovation is not viewed appropriately as a linear process, but rather as a social and interactive process (Lundvall, Borras 1997). For 16 years, the European Union has been trying to achieve the goals which were set in the Lisbon Strategy by the initiative of European Research Area. The goals of the initiative are:

1) to enable researchers to move, interact and benefit from world-class infrastructures, and work with excellent networks of research institutions;

2) to share, teach, value and use knowledge effectively for social, business and policy purposes;

3) to optimize and open European, national, and regional research programmes;

4) to make more coherent use of public instruments and resources;

5) to develop strong links with partners around the world so that Europe benefits from the worldwide progress of knowledge, contributes to global development, and takes a leading role in international initiatives to solve global issues;

6) to develop essential "critical mass" in the major areas of progress in knowledge, in particular to achieve economies of scale, to better allocate resources overall, and to reduce negative externalities due to the insufficient

\footnotetext{
* Joanna Ligenzowska - M.Sc., University of Agriculture in Krakow, Faculty of Agriculture and Economics, Department of Economics and Economic Policy
} 
mobility of factors and poor information for operators (Innovation System Guidebook 2010).

As a result of these premises, a new vision of development has occurred in the field of regional geography and regional planning. What has been termed "new regionalism" has emerged with an integrative approach that ties together the local with the global, micro with macro, as well exogenous with endogenous developments in a wide array of regional scales (Soja, 2009). In particular, a theoretical framework that takes these ideas of knowledge and innovation into the regional development and planning perspective is the "Regional Innovation Systems". An innovation system can be defined as a "group of private firms, public research institutes, and several of the facilitators of innovation, who in interaction promote the creation of one or a number of technological innovations (within a framework of institutions) which promote or facilitate the diffusion or application of these technological innovations" (Beije 1998, p. 256). In the case of Sweden, the turn from welfare to entrepreneurial regionalism was quite evident. Now Sweden is one of the leaders of innovation in Europe and in the world. Largely, this is down to a more decentralized approach where, in essence, each municipality has to fend for itself in the increasingly competitive global environment (Nilsson 2011). This paper describes the role of innovations in Sweden and Swedish regions, both in development and in growth. Additionally, the article highlights the actors and associations from the innovation system perspective. An analysis of the policy documents and a literature overview was the basis of the empirical material. Data comes from the OECD and EUROSTAT databases.

\section{Innovations in Sweden}

Swedish growth since the mid-19th century has largely been a success story. In about 1850, the Swedish income level was close to the global average, according to Maddison. From a European perspective, though, Sweden was a rather poor country. By the 1970s, however, the Swedish income level was more than three times the global average and among the highest in Europe. From the mid-1970s, especially with the appearance of the microprocessor, electronics became central to Sweden's growth strategy. The use of knowledge and information in the production of goods and services advanced rapidly, marking new directions of growth, which coincided with a shift in employment from industry to services. Thanks to the information revolution, Sweden has been one of the most innovative countries in the world for almost five decades (Schön 2009). Each year, Harvard Business School compiles a National Innovation Capacity Index, a study of different countries' innovation potential. In 2010, Sweden was ranked first among 173 countries (Innovation Capacity Index 2010). In terms of the number of trained engineers per capita, Sweden was ranked second, close behind Japan. The study also notes that 
in the past 15 years, Sweden has had the second-fastest growth rate in the number of patents per capita. INSEAD Business School's Global Innovation Index from 2011 ranks Sweden in second place once again. The index measures the degree to which countries have an infrastructure that enhances a creative environment and allows for innovation, as well as actual output. Sweden has strengths in terms of both output and input. Strong output is demonstrated in the many new published research and technical papers, and the many registered patents. Sweden is also seen to have a good input basis, with a stable political climate and a relevant, high-quality education (Swedish Institute 2011). In addition, The Innovation Union Scoreboard 2010, an index published by the European Commission, ranks Sweden as the leading country for innovation among EU member states. Reasons for this include a historic tradition of inventors, a commitment to gender equality, and a strong belief in the individual. Close collaboration between research institutes and the private and public sectors is another key factor, setting the foundation for global Swedish companies like AstraZeneca, Ericsson, and Volvo. Innovation is closely linked to research and development. Sweden is one of Europe's top three spenders in this area, investing 3.6 per cent of GDP in R\&D in 2009. Compare this with the EU-wide target of 3 per cent GDP investment by 2020, and it's clear that Sweden is ahead of the game.

Figure 1. The most innovative countries in the European Union in 2010

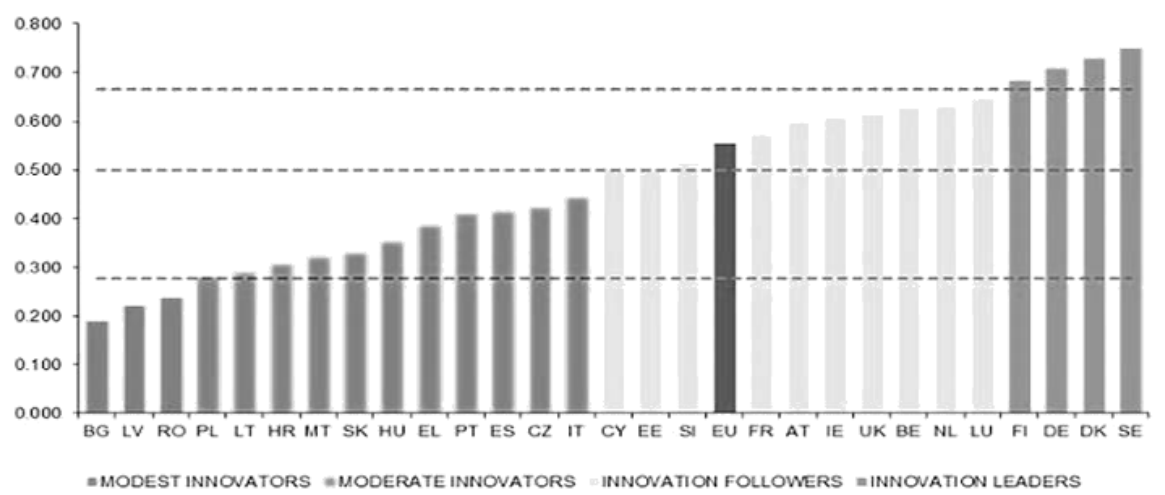

Source: European Union Scoreboard 2010.

The source of success of the Swedish economy is rooted in the cooperation between different actors, public and private. There is an extensive network of organizations and companies, in the public and private sectors, working with academic bodies in Sweden. They aim to develop new products, services and processes that will make long-term contributions to sustainable growth. To name just a few:

1) The Knowledge Foundation (KK-stiftelsen) aims to stimulate competitiveness by creating conditions for innovation and creativity, and by strengthening the links between academia and industry. 
2) The Swedish Foundation for Strategic Research (SSF) is an independent organization that supports research in the natural sciences, engineering, and medicine.

3) The Swedish Governmental Agency for Innovation Systems (Vinnova) focuses on innovations linked to research and development; particularly information and communication technology (ICT), biotechnology, working life, materials, and transportation and bringing products to production.

4) The Swedish Agency for Economic and Regional Growth (Tillväxtverket) is a government body that aims to foster greater enterprise growth and sustainable, competitive business and industry throughout Sweden (Swedish Institute 2011).

Sweden stands relatively strong in most international comparisons of countries' innovation capacities and competitiveness. However, global competition is increasing between companies and nations. Thus, Sweden has created a new Innovation Strategy. The strategy presents long-term guidelines for how the work within many policy areas until 2020 can create better conditions for people in all parts of society to contribute to a more innovative Sweden through their knowledge, skills, and creativity (Swedish Institute 2011). The purpose of this strategy is to contribute to a climate with the best possible conditions for innovation in Sweden with the year 2020 in sight. The work is about:

1) identifying and rectifying areas where today there are obstacles to innovation, or where Sweden reveals weaknesses in international comparisons

2) protecting and developing areas in which Sweden is currently strong in comparison with other countries

3) improving coordination between policy areas, between different levels and social sectors in order to make public initiatives more effective and have the biggest possible impact on renewal, sustainable growth, and social development in Sweden (The Swedish Innovation Strategy 2011).

\section{National Innovation System and Regional Innovation System}

The concept of a national innovation system rests on the premise that understanding the linkages among the actors involved in innovation is key to improving technology performance. Innovation and technical progress are the result of a complex set of relationships among actors producing, distributing, and applying various kinds of knowledge. The innovative performance of a country depends, to a large extent, on how these actors relate to each other as elements of a collective system of knowledge creation and use, as well as the technologies they use. Innovation systems can be defined as follows: 
1) ".. the network of institutions in the public and private sectors whose activities and interactions initiate, import, modify and diffuse new technologies." (Freeman 1987).

2) ".. the elements and relationships which interact in the production, diffusion and use of new, and economically useful, knowledge ... and are either located within or rooted inside the borders of a nation state." (Lundvall 1992).

3) " $\ldots$ a set of institutions whose interactions determine the innovative performance ... of national firms." (Nelson 1993).

4) ".. the national institutions, their incentive structures and their competencies, that determine the rate and direction of technological learning (or the volume and composition of change generating activities) in a country." (Patel, Pavitt 1994).

5) ".. that set of distinct institutions which jointly and individually contribute to the development and diffusion of new technologies and which provides the framework within which governments form and implement policies to influence the innovation process. As such it is a system of interconnected institutions to create, store and transfer the knowledge, skills and artefacts which define new technologies" (Metcalfe 1997).

Innovation systems can have a national, regional, sectoral, or technological dimension. According to Edquist (1997, p. 187), the most important function of an innovation system is the generation and diffusion of knowledge and the related innovative output. The components of an innovation system consist of a bundle of actors as well as institutional rules defining the "rules of the game". They are defined by the institutional structures of the system (be it a country, region, sector, or technology), its incentive system, the skills and creativity of the innovation and the economic actors, and the cultural peculiarities of the specific area or field (Nelson 1993, pp. 517-520; Patel, Pavitt 1994). The added value of an innovation system lies in the relations among the different components. Heuristic innovation system models like the one developed by Kuhlmann and Arnold (2001, Figure 2),provide a more detailed breakdown of actors. At the macro perspective, the major constituents are the industrial sector, the education and research sector, the intermediaries, and the political system. These are influenced by, and they themselves influence, the infrastructure, the demand, and several framework conditions like the relevant institutions. At the meso perspective (regional level), the industrial sector comprises small and large manufacturing and service firms among others, the research sector consists of higher education organizations and non-university research institutes, the intermediaries of technology transfer organizations (TTOs) and chambers of industry and commerce, and the political system of the parliament, government, and its ministries. 
Figure 2. An Innovation Model of Sweden's Economy

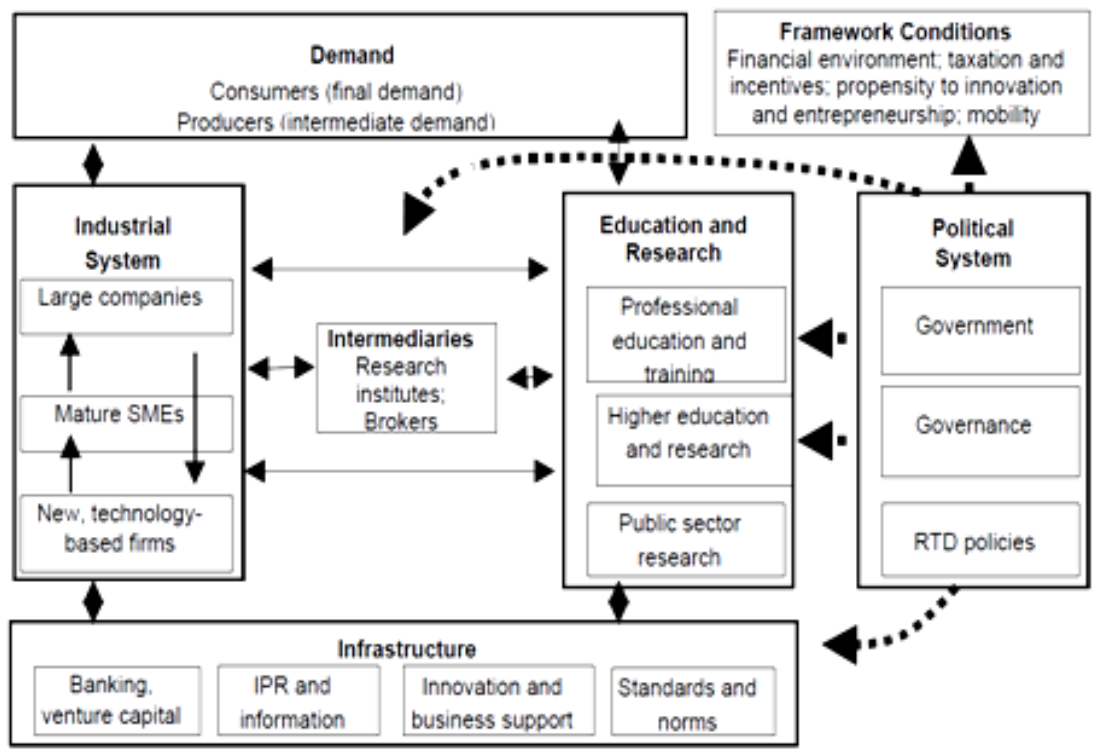

Source: Kuhlmann, Arnold 2001.

For more than twenty years, regions have grown in importance as a competitive location of economic activities in learning economies (Asheim, Isaksen 2002; Cooke 2001). The concept of a regional innovation system (RIS) is a relatively new one, which appeared in the early 1990s (Cooke 1992, 1998, 2001), a few years after Chris Freeman first used the innovation system concept in his analysis of Japan's economy (Freeman 1987), and approximately at the same time as the idea of the national innovation system was becoming more widespread, thanks to the books by Lundvall (1992) and Nelson (1993). Characteristic of a systems approach to innovation is the acknowledgement that innovations are carried out through a network of various actors underpinned by an institutional context. This dynamic and complex interaction constitutes what is commonly labelled as the system of innovation (Edquist 1997). Recent years have seen the establishment of numerous initiatives such as clusters, clubs, or entrepreneur networks, which are now playing a role in the stimulation of regional innovation activities. The RSI approach thus highlights the regional dimension of the production and the exploitation of new knowledge, thereby helping to explain regional differences in innovation capacity and economic strength (Schrempf, Kaplan, Schroeder 2012). RSIs usually consist of a set of interacting private, semi-private and public organizations, interacting within an institutional framework. This framework supports the generation, exploitation, and dissemination of knowledge, and thus supports innovative activities ata regional level (Asheim, Coenen, Svensson-Henning 2003; 
Cooke 2004; Doloreux 2003). There have been several attempts to understand and structure the research conducted under the umbrella of RSI (see D'Allura et al. 2012; Asheim, Gertler 2005). According to Doloreux and Parto (2005), RSI research focuses on three main dimensions:

1) firstly, the interactions between the actors of the innovation system in relation to the exchange of knowledge;

2) secondly, the set-up and the role of institutions supporting knowledge exchange and innovation within a region; and

3) thirdly, the role of RSI in regional innovation policy-making.

Taking each element of the term in turn, the concept of the region highlights an important level of governance of economic processes between the national level and the level above the local or municipal level. Regions are important bases of economic co-ordination at the meso-level, although the level of regional administration can differ quite a lot across various countries (Asheim et al. 2003; Cooke et al. 2000).The regionally networked innovation system is a result of policy intervention to increase innovation capacity and collaboration. SMEs, for example, may have to supplement their informal knowledge (characterized by a high tacit component) with competence arising from more systematic research and development in order to carry out more radical innovations. In the long run, most firms cannot rely exclusively on informal localized learning, but they must also gain access to wider pools of both analytical and synthetic knowledge on a national and global basis. The creation of regionally networked innovation systems through increased co-operation with local universities and $R \& D$ institutes, or through the establishment of technology transfer agencies, may provide access to knowledge and competence that supplements firms' locally derived competence (Asheim, Coenen 2005).

Figure 3. The concept of RSI, showing the main actors and dimensions and how they interact

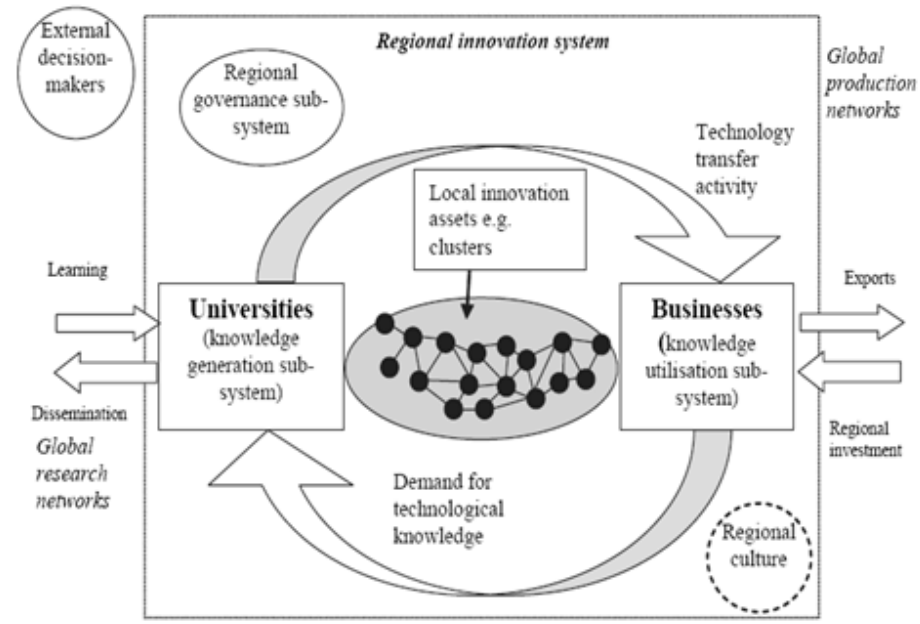

Source: Cooke, Piccaluga 2004. 


\section{Regional Innovation System in Sweden}

The Swedish economy can be considered a mixed economy of free-market activities and government interventions. Although liberalization in recent decades has affected the system, the welfare state model is still prevalent, perhaps more than in any other European country. One can thus expect a national system of innovation with surplus value at the national level over and above the sum of the regional innovation systems. The modern nation state has further been developed since Napoleonic times, reinforcing a national identity that has been shaped since the Reformation. The knowledge infrastructure of Sweden is centralized in three metropolitan areas: Stockholm, Gothenburg, and Malmö. The capital region of Stockholm hosts the Karolinska Institute - one of Europe's largest medical universities - Stockholm University, the Royal Institute of Technology, and the Stockholm School of Economics. Uppsala University (founded in 1477) is located in the neighboring county of Stockholm. Gothenburg, located in VästreGöthaland, hosts the University of Gothenburg and Chalmers University of Technology. The largest university, Lund University, is located in Skåne (that is, the region surrounding Malmö).

Figure 4. Location of the 21 Swedish counties at the NUTS 3 level

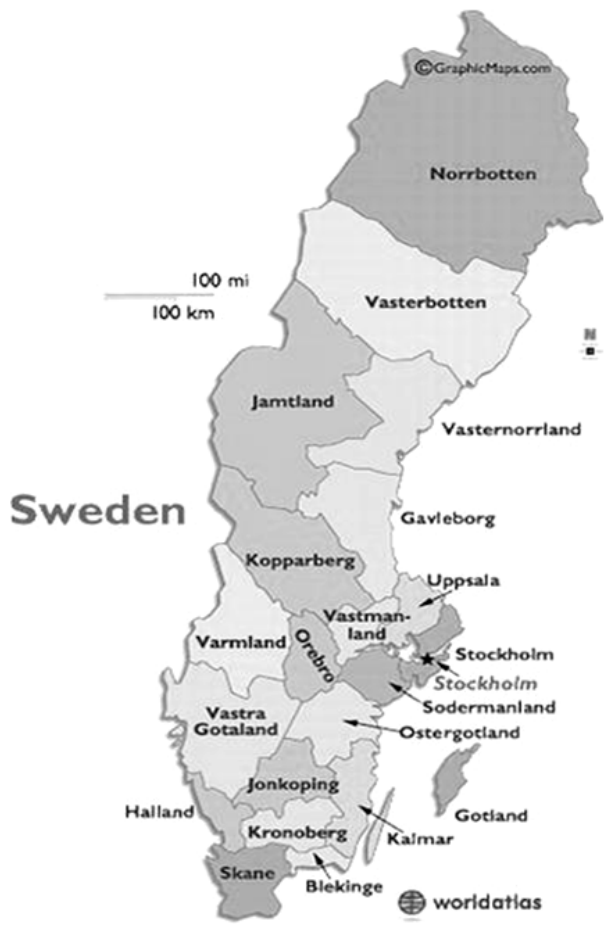

Source: www.worldatlas.com, 2016. 
Sweden is organized at three levels of government: the central government (NUTS level 0), 21 counties (at NUTS level 3, Figure 2) and 290 municipalities (at NUTS level 5). During recent years, innovation has become more important as the focus of Swedish regional policy has shifted from regional redistribution, to regional development, and now to regional growth. National initiatives have been taken to encourage regional actors at the county level to develop regional innovation strategies and to create competitive platforms for competence development. Further, higher educational institutions have been encouraged to increase their collaboration.

\section{South Sweden}

South Sweden is a growth region both from a national and European perspective, with an internationally competitive industry in different sectors. The NUTS 2 region of South Sweden (Sydsverige) consists of two relatively independent NUTS 3 regions, Skåneand Blekinge. In December 2012, Skåne had a total of 1,263,088 inhabitants, including Sweden's third largest city region, Malmö, with 307,758 inhabitants. Blekinge had 152,315 inhabitants. Malmö (the regional administrative capital), Helsingborg and Lund are the main cities in the region of Skåne (33 municipalities), and all three are located near or along the Öresund strait. The region has strong clusters with adjustment and development capability, large investments in industries that strengthen competitiveness, strong research and innovation environments, and large R\&D investment. As such, the regional innovation system is generally varied and functions well, with a regional structure that is well integrated (Johnsen, Olsen 2014). The GDP per capitain South Sweden in 2011 was $€ 34,800$, well above the EU27 average of $€ 25,200$, but below the national average of $€ 40,800$ (EUROSTAT 2014). The average level of unemployment in South Sweden in 2012 was $9.4 \%$, which is above the national average of $8.0 \%$. The region also has a higher long-term unemployment rate than the nation as a whole ( $2 \%$ compared to $1.4 \%$ respectively), even though the rate is low compared to the EU27 average of 5.1\% (EUROSTAT 2013).

The proportion of the population employed in the region is below the national average, although this difference has diminished significantly in recent years. The companies in the region invest heavily in $R \& D$ compared to the nation as a whole and the EU27, and the total R\&D personnel as a percentage of the active population in the region is high $(2.4 \%)$. The share of technological (product or process) innovators as a percentage of all SMEs is also slightly higher than the EU27 average, and business R\&D expenditures as a percentage share of GDP is considerably higher in South Sweden than the national average (3.3\% compared to $2.3 \%$ respectively), although the share has seen a steady decrease since 2007 (EUROSTAT 2013). The share of R\&D expenditures as a percentage of GDP has also decreased since 2009; however, the percentage share of R\&D expenditures 
from higher education has remained stable in the same period (EUROSTAT). The $1.1 \%$ share of GDP spent on R\&D in higher education is higher than the national average of $0.9 \%$ and considerably higher than the $0.5 \%$ average in the EU27 (EUROSTAT 2013). Government investment in R\&Dasa percentage of GDP in South Sweden is well below the EU27 and national average, although there has been a slight increase the past few years; in 2011, government R\&D made up slightly more than $0.1 \%$ of GDP, compared to $0.25 \%$ in the EU27(EUROSTAT 2013).

The rate of enterprise creation is relatively high, especially in Skåne, which can partly be explained by the fact that larger city regions tend to innovate more. However, studies of South Sweden have shown that relatively large resources are invested in early stages to capture ideas that have the potential to become new companies, but that the support structure for companies in the growth stage are weak. For instance, the structure for capturing service innovations has been especially weak and the availability of venture capital too small. At the current stage, R\&D investments in South Sweden are largely driven by business; the government only invests $0.12 \%$ of GDP in R\&D and only $1.09 \%$ in higher education (EUROSTAT 2013). The high proportion of private research involves the results being commercialized, to a large extent (which might help explain the high number of EPO patent applications), but it also means that the region's R\&D efforts are largely driven by a few companies, which creates a certain vulnerability for the region. South Sweden is part of the larger national innovation system, and the regional governance structure is a mixture of public and private initiatives, involving actors at different levels. To involve various actors, several clusters and cooperative platforms have been established (Johnsen, Olsen 2014).

The region of Skåne includes seven cluster initiatives working to strengthen the competitiveness of companies in the region, in particular: the Skåne Food Innovation Network, Mobile Heights, Media Evolution, the Sustainable Business Hub, Packbridge, Resilient Regions (previously Training Regions) and Medicon Valley Alliance (a cross-border initiative). The Skåne cluster initiatives have successfully supported companies in Skåne for a long time in their efforts to becomemorecompetitive.South Sweden has, during recent years, focused on strengthening clusters in existing key areas in order to promote innovation. However, to find solutions to new challenges, such as the global climate threat, the financial crisis, and the increased share of elderly people, it has become evident that different industries and areas of expertise have to join forces and develop the products of the future together. Examples of support measures to strengthen the priority areas are: Öresund Smart City Hub, ICT Skåne (Mobile Heights), Cleanovation - Innovation network for adaptation to cleantech, ESS MAX (TITA), ICT Blekinge (BICT 1 and 2), Media Evolution. 


\section{West Sweden}

The NUTS 2 regions in Sweden do not always correspond to traditional geographical or economic regions. The NUTS 2 region of Västsverige (West Sweden), with approximately 1,900,000 inhabitants, consists of two relatively independent NUTS 3 regions. In 2012, the larger Västra Götaland region had a total of around 1,600,000 inhabitants, including Sweden's second largest municipality, Gothenburg (526,000 inhabitants). The smaller Halland region had approximately 304,000 inhabitants. The average gross domestic product (GDP) during the period 2000-2010 was 536,600 SEK ( $€ 60,099 \mathrm{~m})$, or close to $19 \%$ of national GDP (Gross Domestic Product). Most sectors of the Swedish economy were represented in the region, except for some parts of the financial sector, which are focused on Stockholm, and certain sectors related to natural resources. In 2008, the percentage of gross value added (GVA) in the manufacturing industry (about 30\%) and wholesale/retail (about 20 per cent) was above the national average (RIM repository 2013). The GDP per capita in West Sweden in 2010 was $€ 35,300$, well above the EU27 average, but the $2.61 \%$ growth in GDP per capita between 2000 and 2010 was lower than the EU27 average (2013). In 2009, the region experienced a negative GDP growth rate, however, as early as 2010, the region experienced much higher GDP growth than the EU27 (19.8\% compared to 4.5\% respectively) (EUROSTAT 2013).

The economy in West Sweden is characterized by a number of strong growth areas where the region has specific competitive advantages in an international perspective. The Port of Gothenburgis Scandinavia's largest port with trans-ocean and intra-European shipping lines. The Gothenburg area is the hub of the Nordic transportation system and half of Sweden's import/export goes through the area. The region is attractive to foreign investment, and it has a significant number of foreign-owned firms. Companies like Volvo, Saab, Astra Zeneca, SKF, and Ericsson are all present in the region, while there is also a large share of SMEs present. The average level of unemployment in 2012 was close to the national average in Västra Götaland (8.0\%), but as low as 6.4\% in Halland (RIM repository 2013). Regarding employment distribution between sectors (2011), $48 \%$ of the workforce is employed in knowledge intensive services, while employment in medium-high and high-tech manufacturing is 6.5\% (EUROSTAT 2013). To strengthen regional resilience, attention to services sectors has increased; however, employment in these sectors is still below the national average (EUROSTAT 2013). Employment in high tech industries and knowledge intensive services is high compared to the national and EU27 average. The total R\&D personnel account for $2.49 \%$ of the active population in West Sweden, compared to only $1.53 \%$ in the EU27 (EUROSTAT 2013).

Therefore, regional policy focuses on strengthening the industry's ability to stay innovative and globally competitive, while mastering the transformations 
needed to meet societal challenges as a result of global economic crisis, social unrest, and climate change. The region's future competitiveness and attractiveness for innovation, knowledge intensive production, and R\&D is one of the most prioritized issues for policy. West Sweden is consistently high in terms of innovation. When comparing the number of patents, the number of R\&D employees, and $R \& D$ expenditure, the region is ranked sixth out of 214 European regions (Swedish Agency for Economic and Regional Growth 2011). In a more recent survey from 2012, West Sweden, together with Stockholm, are ranked among the leading regions when it comes to conditions and outcomes of innovation in the economy (European Commission 2012). Conditions for innovation in West Sweden are good and there is a comprehensive support structure to promote entrepreneurship and innovation. $R \& D$ intensity is high also from a global perspective; the annual business R\&D expenditure is more than three times the EU average (3.3\% of GDP in 2011 compared to $1.2 \%$ in the EU27) (EUROSTAT 2013). However, government investment in R\&D is well below the EU average; in 2010 government R\&D only made up $0.1 \%$ of GDP, compared to $0.2 \%$ at the national level and $0.3 \%$ in the EU27 (EUROSTAT 2013). In comparison, higher education R\&D expenditure is considerably higher in West Sweden at $0.8 \%$ of GDP compared to the EU27 average of $0.5 \%$ (EUROSTAT 2013).

The business innovation indicators also show that the percentage of innovative SMEs collaborating with others is higher in West Sweden than at the national level and the EU27 (EUROSTAT 2013). Two important sectors are automotive manufacturing and trade. Other key sectors have been prioritized in the regional development process, e.g. life science, tourism, food processing, textiles, ICT, the petrochemical industry, environment/energy, and maritime industries. Several of these are part of national $R \& D$, innovation systems or cluster programmes, e.g. Smart textiles, GöteborgBio and Hälsoteknikalliansen. There are some large multinational firms headquartered in the region, like Volvo and Astra Zeneca, but due to an increased share of foreign ownership, the region is relatively vulnerable to external decisions. On average, it is business in the region that spends most on R\&D, when measured in euro per inhabitant (EUROSTAT 2013). The innovation support structure consists of a variety of organizations and measures to support the development of innovations and business ideas from the conceptual stage through to market launch.

To stimulate innovation, a number of platforms have been established in cooperation with public and private stakeholders, e.g. Sahlgrenska Science Park, Lindholmen Science Park and Johanneberg Science Park in Gothenburg, Innovatum in Trollhättan, Espira in Borås, and Gothia Science Park in Skövde. During the past ten years, a large number of technology-based companies have emerged in the region, often through university-based incubators, and with the support of seed capital. Many successful examples exist, such as the Chalmers Innovationfoundation, which has contributed to the development of a considerable number 
of new technology-based companies (Johnsen \& Fredricsson, 2014). Important actors in the regional innovation system are the four sub-regional bodies, which should support the implementation of the VG2020 and innovation measures. Each sub-region has a specific organization that works to promote local business development:

1) Business Region Göteborghas the main responsibility for businessdevelopment in the Gothenburg Region and works to strengthen and develop trade and industry in the Gothenburg region.

2) Industrial Development Sweden works in Skaraborg to coordinate efforts to stimulate industrial development and innovation;

3) IUC Sjuhärad operates in the Sjuhärad Region and supports small and medium sized companies in terms of business development;

4) The adaptation office - Fyrboda (Omställningskontoret) - is responsible for promoting regional growth, employment, and supporting local businesses in the Fyrbodal region (Johnsen\&Fredricsson, 2014).

\section{Northern Central Sweden}

The NUTS 2 region of North Middle Sweden (Norra Mellansverige) is an area developed mainly for the design and implementation of European Regional Development Funds (ERDF) 2007-2013. It is a sparsely populated region, with approximately 826,000 inhabitants, consisting of three independent NUTS 3 regions (län). The GDP per capita in 2008 was slightly above the 27 countries of European Union average, but the growth rate has been low for many years. The region is well endowed with national resources and has traditionally been dominated by capital-intensive export industries, such as pulp and paper, steel, and engineering, machinery, and transport vehicles. Employment in high tech industries and knowledge intensive services is rather low and even though the share of the population with a higher education is slowly increasing, it is still below the national and EU27 average. In North Middle Sweden, there is one university, Karlstad University (in Värmland), and two university colleges, in Dalarna and Gävleborg, but the share of government R\&D funding is limited. The annual commercial R\&D expenditure is also below the EU average, since many of the larger companies are part of multinational groups. Still, the region is doing rather well in terms of number of patents, which may be a consequence of the interest in applied research among some of the larger technology-based firms in the region (Lindqvist 2012). This has been a long-term trend.

Between 1996 and 2003, the average annual change in GRP was 2.6\%, providing North Middle Sweden with a rank of 237 among the 246 NUTS 2 regions in the EU25 (Swedish Agency for Economic and Regional Growth 2011).The structural change in traditional sectors has resulted in the increased attention of other sectors, such as food processing, ICT, and tourism. Over the last ten years, 
employment in the ICT sector has increased rapidly and the region has a strong position with a well-developed ICT infrastructure. In the municipality of Hudiksvall, for example, $96 \%$ of the inhabitant have access to broadband, compared to an average coverage of 13\% in Europe (Swedish Agency for Economic and Regional Growth 2011). The government research and development (R\&D) expenditures are mainly directed towards universities and research institutes. Even though the number of researchers and the level of $R \& D$ funding have increased over the last years, only about $1.7 \%$ of government R\&D funding to universities was allocated to Karlstad University in the Swedish state budget 2011(Swedish Government 2010). In addition, private $R \& D$ expenditures are relatively limited in the region. The annual business R\&D expenditure in 2007 was $1.02 \%$, well below the national average but also below the EU average (Swedish Government 2010). In North Middle Sweden, the level of regional autonomy concerning regional innovation policies is considered to be quite high. The main responsibility for regional development, including the development and implementation of RUP, is held by the three Regional Development Councils; Värmland Region, Dalarna Region and Gävleborg Region. However, as North Middle Sweden is not a traditional or functional region, there is no single body responsible for regional innovation policy, and the integration of the formal governance structures of the three NUTS 3 regions of Värmland, Dalarna and Gävleborg is quite limited.The innovation support structure in each county consists of a variety of organizations and measures, including cluster organizations, regional financial and advisory services on business development, business incubators, and higher education institutions. Since it gained university status in 1999, Karlstad University has become an increasingly important resource for innovation and collaboration, particularly in Värmland. Today, the university is in close cooperation with the regional business community in several of its research areas, often through the regional cluster organizations. Since North Middle Sweden is not a traditional or functional region, there is no specific innovation strategy or policy for coordination of support to research, technological development, and innovation (RTDI) at the NUTS 2 level. However, there has been an increased focus on cluster policy development to support innovation and entrepreneurship over the last ten years (Lindqvist 2012).

\section{Conclusion}

The main objective of this article was to present the innovation activity in Swedish regions, based on Regional Innovation Systems, and to examine the characteristics of innovation actors in particular. The findings were based on empirical evidence from Eurostat and the scientific literature. An innovation system can be defined as a "group of private firms, public research institutes, and several of the facilitators of innovation, who in interaction promote the creation of one or 
a number of technological innovations (within a framework of institutions) which promote or facilitate the diffusion or application of these technological innovations" (Beije 1998, p. 256). According to the European Regional Innovation Scoreboard 2014 (European Commission, 2012), Sweden is among the innovation leaders, with an innovation performance well above that of the EU average. Sweden is one of the countries with the highest proportions of research in terms of GDP, and the majority of the investments in research and development (R\&D) are made by industry. Swedish regions have also taken a leadership role in that statistic. The innovation support structure consists of a variety of organizations and measures to support the development of innovations and business ideas from the conceptual stage through to market launch. Moreover Sweden has compiled the Innovation Strategy 2014-2020, which aimed to: develop the work with long-term regional strategies, with particular focus on strong innovation environments such as clusters, develop the interaction between national authorities, regional development actors, and the work with projects and programmes within the EU, and continue to promote learning in the context of regional growth, both nationally and regionally, by e.g., developing the use of policy intelligence and evaluations.

\section{Bibliography}

Asheim B. T., Coenen L., Svensson-Henning M. (2003) Nordic SMEs and Regional Innovation Systems - Final Report. Oslo, Nordic Industrial Fund (http://www.nordicinnovation.net).

Asheim B. T., Gertler M. S. (2004), Regional Innovation Systems and the Geographical Foundations of Innovation, [in:] Fagerberg J., Mowery D., Nelson R. R. (eds.), The Oxford Handbook of Innovation. Oxford.

Asheim B. T., Isaksen A. (2002), Regional Innovation Systems: The Integration of Local 'Sticky' and Global 'Ubiquitous' Knowledge, "Journal of Technology Transfer", Vol. 27.

Beije P. (1998), Technological change in the modern economy: basic topics and new developments, Cheltenham.

Cooke P. (1992), Regional Innovation Systems: Competitive Regulation in the New Europe, Geoforum 23.

Cooke P. (1998), Introduction: Origins of the Concept, [in:] Braczyk H., Cooke P., Heidenreich M. (eds.) (1998) Regional Innovation Systems, London.

Cooke P. (2001), Regional Innovation Systems, Clusters, and the Knowledge Economy, "Industrial and Corporate Change", Vol. 10 (4).

Doloreux D. (2002), What We Should Know About Regional Systems of Innovation, "Technology in Society", Vol. 24.

Edquist C., 1997. Introduction, [in:] Edquist, C. (ed.), Systems of Innovation: Technologies, Institutions and Organisations, London. 
European Regional Development Fund, (2010), Innovation System Guidebook, http://eit.europa.eu (8.02.2016).

European Commission (2010), Innovation Union Scoreboard 2010.The Innovation Union's performance scoreboard for research and Innovation, Directorate-General for Enterprise and Industry, February 2011.

European Commission (2010), European Competitiveness report 2010. An integrated Industrial Policy for the Globalisation Era Putting Competitiveness and Sustainability at Front Stage, Directorate-General for Enterprise and Industry, SEC (2010) 1272.

EUROSTAT, http://ec.europa.eu/eurostat (8.02.2016)

Florida R. (2003), The Learning Region [in:] Zoltan J. A. (ed.) Regional Innovation Knowledge and Global Change, London.

Freeman C. (ed.) (1987) Technology policy and economic performance: Lessons from Japan. London.

Johnsen I., Olsen L. (2014), Regional Innovation Monitor Plus - Southern Sweden.

Johnsen I., Fredricsson Ch. (2014), Regional Innovation Monitor Plus - West Sweden.

Kuhlmann S., Arnold E. (2001), RCN in the Norwegian Research and Innovation System. Background report No 12 in the evaluation of the Research Council in Nor-way, Royal Norwegian Ministry for Education, Research and Church Affairs, Oslo.

Lindqvist M. (2012), Regional Innovation Monitor Plus - Northern Central Sweden.

Lundvall B.-Å., Borras S. (1997) The Globalising Learning Economy: Implications for Innovation Policy, European Communities, Luxembourg.

Lundvall B-Å. (ed.) (1992), National Systems of Innovation: Towards a Theory of Innovation and Interactive Learning, London.

Maddison A. (2006) The World Economy. Vol. 1-2, OECD.

Metcalfe I. (1997), National Innovation System, OECD.

Nelson, R.R. (ed.) (1993), National Innovation Systems. A Comparative Analysis, New York.

Nilsson, L. (2011), Efter Industrialismen: Urbaniseringoch Tätortsutveckling I Sverige 1950-2005, Malmö.

OECD (2010), Innovation Strategy: Innovation to Strengthen Growth and Address Global and Social Challenges.

OECD (2012), Main Science and Technology Indicators, 2012/1, Paris.

Patel P., Pavitt K. (1994), National innovation systems: why they are important and how they might be measured and compared, "Economics of Innovation and New Technology", Vol. 3.

Schön L., (2004), Total Factor Productivity in Swedish Manufacturing in the Period 1870- 2000, In Exploring Economic Growth: Essays in Measurement and Analysis, [in:] Heikkinen S., van Zanden J.L. (eds.), A Festschrift for Riitta Hjerppe on Her Sixtieth Birthday, Amsterdam. 
Soja E.W. (2009), Regional Planning and Development Theories [in:] Thrift N., Kitchin R. (eds.), International Encyclopedia of Human Geography, Oxford UK. Storper M. (1997), The Regional World. Territorial Development in a Global Economy, New York and London.

Swedish Agency for Economic and Regional Growth (2011), Statistik, (https:// tillvaxtverket.se/statistik.html).

Swedish Institute (2011), The Swedish Innovation Strategy, N2012.33.

\section{Summary}

Over the past two decades, social scientists and governments have been paying more and more attention to regions as designated sites of innovation and competitiveness in the globalizing economy. Thus, innovation and innovation systems are becoming increasingly interesting to policy-makers as ways of achieving their economic and social goals. Europe 2020, the European Union's key strategy for the current decade, aims to foster a smart, sustainable, and inclusive economy. "Innovation has been placed at the heart of the strategy", as it provides the "best means of successfully tackling major societal challenges" (European Commission 2010, p. 2). The new age of capitalism requires a new kind of region. In effect, regions are increasingly defined by the same criteria and elements which comprise a knowledge-intensive firm: continuous improvement, new ideas, knowledge creation and organizational learning (Florida 2003, p. 236). The increased policy and research interest in regional clusters and innovation systems reflects the growing significance of the regional level, and the importance of specific and regional resources, for stimulating the innovation capability and competitiveness of firms. The social and interactive practice of innovation also points to the importance of the relationship between the firm and its environment. The learning economy perspective affirms that learning and innovation are localized, not placeless processes (Storper 1997). Thus, it emphasizes that innovation is a territorially-embedded process, based not only on resources that are place specific but also on social and institutional contexts (Asheim, lsaksen 2002). This paper describes the role of innovations in Sweden and Swedish regions in development and growth, mainly by analysing the concept of regional innovation systems. Moreover, the actors and associations from the innovation system perspective are pointed out in the article. An analysis of the policy documents and a literature overview was the basis of the empirical material. Data comes from the OECD and EUROSTAT databases.

Keywords: regional innovation systems, knowledge bases, institutions, Sweden 


\section{Streszczenie}

\section{Regionalne systemy innowacji w Szwecji}

Przez ostatnie dwie dekady rządy i naukowcy poświęcali coraz więcej uwagi regionom, jako jednostkom budowania innowacyjności i konkurencyjności w zglobalizowanym świecie. Innowacje i systemy ich wspierania stały się ważnym narzędziem dla osiągania celów polityki gospodarczej. Europa 2020, kluczowa koncepcja strategiczna UE na najbliższe lata, skupia się na tworzeniu gospodarki trwałej, inkluzyjnej i wykorzystującej wiedzę. Innowacje umieszczono „w sercu strategii”, jako najskuteczniejszy środek ,radzenia sobie z wyzwaniami społecznymi" (European Commission 2010, s. 2). Nowa era kapitalizmu wymaga jednak nowego podejścia do regionów. Regiony coraz częściej traktowane są jak przedsiębiorstwa oparte na wiedzy, w których najważniejszymi kryteriami oceny i elementami są: ciągła poprawa, nowe pomysły, tworzenie wiedzy i uczenie się na poziomie organizacji (Florida 2003, s. 236). Wzrost zainteresowania klastrami regionalnymi i systemami innowacji na płaszczyźnie badań i polityki gospodarczej wskazują na wzrost znaczenia specyficznych zasobów regionalnych dla pobudzania innowacyjności i konkurencyjności przedsiębiorstw działających w obrębie danego regionu. Ważne stają się także interakcje między firmami i ich otoczeniem, ponieważ procesy uczenia się oraz generowania innowacji są ściśle powiązane ze swoimi lokalizacjami (Storper 1997). Kluczowe stają się zatem nie tylko zasoby regionalne, ale także regionalny kontekst społeczny i instytucjonalny (Asheim, Isaksen 2002). Niniejsza praca opisuję rolę innowacji w rozwoju Szwecji i szwedzkich regionów, skupiając się na analizie przez pryzmat regionalnych systemów innowacji. Wskazano najważniejsze podmioty z punktu widzenia tychże systemów. Podstawę rozważań stanowiły dokumenty kształtujące politykę gospodarczą w Szwecji i jej regionach oraz analiza literatury. Wykorzystano dane statystyczne $\mathrm{z}$ baz EUROSTAT oraz OECD.

Słowa kluczowe: regionalne systemy innowacji, bazy wiedzy, instytucje, Szwecja JEL: O11, O18, R11 